\title{
Repugnancy Doctrine and Customary Law in Nigeria: A Positive Aspect of British Colonialism.
}

\author{
Uweru, Bethel Chuks
}

\begin{abstract}
The doctrine of repugnancy owes it origin to the medieval period and evolution of English equity. The doctrine was introduced into Nigeria by the end of the $19^{\text {th }}$ century via the received English laws to test our customary law for acceptability. The issue has been whether the application of the doctrine by Nigerian courts has an 'English colouring' as a result of colonization. This paper argues that equity did not originate from England; it is a universal concept of what is 'good, just and fair', which is consistent with. S. 36(1) of the 1999 Nigerian constitution. The problem with our customary law is that it is inundated with multiplicity of customs complicated by superstitions. It is difficult to take judicial notice of it without conditionality. The paper concludes by supporting the locus classicus in Eshugbaye Eleko v. Government of Nigeria, and Elias' thesis that the doctrine of repugnancy has a positive effect on the development of our customary law by the removal of its superstitious and harsh elements. This is one positive aspect of British colonialism.
\end{abstract}

Keywords: customary law, repugnancy doctrine, British colonialism.

\section{Introduction}

The state of the literature on the development of our customary law and the doctrine of repugnancy is that:

(i) The British colonized us from $1863-1960$.

(ii) When the British arrived, they met about 350 different tribal or independent kingdoms, some of which were under the influence of the Islamic civilization.

(iii) To facilitate the administration of the colony of Lagos in 1863, the British administered the common law of 
Repugnancy Doctrine and Customary Law in Nigeria: A Positive Aspect...

England until the enactment of the Criminal Ordinance No. 3 in 1904.

(iv) The British administration permitted the application of the rules of customary law provided they pass a general test of validity: not repugnant to natural justice, equity and good conscience or incompatible either directly or by implication with any law for the time being in force.

Thus, since 1863, the Nigerian Law, which has been built on the basis of English Law, co-exists with about 350 customary Laws, subject to the test of validity. The 1886 Charter of the Royal Niger Company provides that in the administration of justice, the customs and laws of the people(s) in its territory must be respected and upheld (Newbury, C. W., (1960). The question has been; why subject our customary laws to a test of validity? Could it be to remove superstitious and harsh elements inherent in them? Or could it be that they lack exactness because of non-codification? Why do courts have difficulty in taking judicial notice of them?

\section{Law and Customs as Products of Social Processes}

A major area in sociology of law is the examination of the influence(s) of social processes upon law and customs and vice versa. In a social system, there exists a bundle of norms: legal, moral, religious, political, traditional, etc. Among these norms, legal and moral norms are distinct as their roles in the social system are particularly significant and important. Moral and legal norms (usually referred to as social norms) are the basis for social order and regulation.

Social norms exist to solve perceived problems or difficulties and as new conditions arrive, society adapts itself to deal with new situations. This is consistent with the dictum of Bairamian, F. J. (as he then was) in Owouyin v. Omotosho (1961) and Obaseki, J. S. C. in Oyewumi v. Ogunsesan (1994) that customary law is an organic norm(s) of the people regulating their behaviour and transactions. It is organic in that it is not static; it is regulatory because it guides and controls the lives and transactions of the people subject to it. 
If one takes a long look around his environment in today's society, it would seem surprising to him that social life exists at all, for people are, generally speaking, selfish, quite oblivious to the needs of others and in the most determined way pursuing their own entirely private interests. Yet society seems to be nothing more than an endless collection of rules and regulations which are designed to limit the freedom of the individual, to ensure that he considers other people before he considers himself and to stifle all his selfish urges. In spite of this situation, society does exist, and the majority of people appear reasonably content to live their daily lives in the company of others, to cooperate with them and to adapt and modify their own behaviour accordingly. The question is, how?

Man is a social animal, and so must interact. Human society has the ability, through adaptation processes, to integrate by socializing its individual members. Society does this through its various agencies: family, school, neighbourhood, peer-groups and mass communication. When a baby is born, it has no instinctive knowledge of what is right or wrong, good or evil; the social norms of society are external and at first have no meaning for him. Through the process of socialization it is expected that these norms will become internalized - that is, the individual will come to accept them as his own. He will however, only accept social norms if he realizes that they are relevant and meaningful to him and his environment. He is unlikely to accept all the social norms wholeheartedly if the society itself and the people with whom he comes into contact do not appear to be agreed about the norms that are being transmitted. This is exemplified in the theories of socialization: social learning theory, cognitive developmental theory and symbolic interactionism (Wiggins, Wiggins and Vander Zanden, 1994).

In the 15th century England, for example, thousands of persons were tortured and put to death for allegedly being members of the witchcraft cult. The reality of witchcraft cult in the period is seen in 
the steps taken by the British Parliament in 1563 when it passed an Act against Conjuration, Enchantments and Witchcraft - (5 Eliz. Cap. 16, 1563 (Seth, Ronald (1960). In the 18th century, witchcraft ceased to be legally prosecuted. The rationalism of this period rejected the objective existence of sorcery and witchcraft, and the witch trials were attributed to bad custom, errors of superstition and fraud. The implication of this is that technological and social changes brought new morality which found the witch trials repugnant to natural justice, equity and good conscience.

\section{Repugnancy Doctrine in Medieval Europe}

Derrett (1965) has suggested that the Repugnancy doctrine can be traced to the Roman - canonical law which had been applied in most of the medieval European states, though he did not explicitly explain how he arrived at that conclusion. The fact is that ancient civilizations (up to about AD 476) such as the Egyptian the Babylonian, the Chinese, Carthaginian, the Greek, the Roman, etc. declined and fell owing mainly to lack of political unity. By the Medieval period, the Romans achieved greatness and learned to govern a large empire. The foundations for their imperial system were laid in the days of the Republic, when many sound and effective features of government were developed - through the influence of the Greeks. Notable amongst Roman contributions to political organizations were its legal codes, which protected citizens from arbitrary rule. As the boundaries of the empire expanded, Romans took their laws and customs with them, subjecting 'Barbarian states' laws and customs to tests, especially when they challenge Roman sovereignty.

The Roman Empire included peoples of many races, religions, and cultural traditions. These diversities made governance difficult and the government faced the challenge of dealing with the Christians. The Christians refused to recognize the Emperor as divine and would not submit to Roman authority. As a result, the Government regarded them as dangerous and subversive and they were persecuted from time to time - especially at times of national crisis when the government 
needed scapegoats to blame for mismanagement and disasters. In persecuting the Christians, Roman law defended their rights, the law provided framework whereby responsible government officials could see to it that rights of citizens were respected. For example, Christians - like all citizens had a right to appear for a hearing in the Emperor's court, there they might receive a fairer hearing than in the provinces. The right of appeal was a treasured one and usually respected, even by the more autocratic emperors (Emiola, Akintunde 1997). Some Historical evidence corroborates this:

(i) Chapter 25, verse $1-21$, Acts of the Apostles in the New Testament, tells a story of St. Paul, who was accused of a number of misdeeds by Jewish leader in Palestine and appealed to the Emperor to assure him of a fair trial.

(ii) Historical writings of Tacitus describe Nero's persecutions in 64 A.D.

(iii) Correspondence between Pliny the Yuunger and the Emperor Trajan about the treatment of Christians in the province of Bithynia in Asia Minor where Pliny was the Emperor's representative.

(iv) A decree of Emperor Hadrian written about 124 A.D. in the form of a letter to a Government official reveals the attitude of the emperor towards men who accused others falsely, and the need to allow appeals to him.

Looking at the development of the repugnancy doctrine in the medieval European states and the historical evidence, we can generalize: that the Romans applied the repugnancy doctrine to the states of the empire and beyond and introduced rules of equity to protect the rights of all citizens.

\section{Nigeria, a British Creation}

The annexation of Lagos by the British colonial authorities in 1861 could be regarded as the real beginning of British colonial conquest of Nigeria. Before the British came, Nigeria as it is known today, was made up of about 350 ethnic nationalities described variously as empires, caliphates, kingdoms, chiefdoms, city-states and village 
republics, each ethnic group is governed by multiplicity of customs which were their grundnorm.

At that time, no ruler or set of rulers of any of the nationalities had any claim(s) of a power - state over any ethnic nationality. The most powerful of them - the Sokoto caliphate, itself about 100 years old in 1900, was encapsulated in the Nigerian system of 1914. The expansionism of the Sokoto caliphate had difficulties in its hold and control over the kingdom of Borno, part of the present day Gongola State, the Benue valley and the forest regions south of the Niger Benue confluence. The other expansionist - oriented systems such a the old Oyo and Benin empires demonstrated limited capabilities for fear of disintegration and limited technological resources.

Eventually, the colony of Lagos, the protectorates of northern and southern Nigeria was amalgamated in 1914 to form the present day Nigeria. Frederick Lugard was appointed Governor-General assisted by two Lieutenant Governors for Northern and Southern provinces of Nigeria and an administrator for the Lagos colony. Thus, the Nigeria nation-state is a British creation.

\section{Repugnancy Doctrine and Customary Law in Nigeria}

To examine the issue of native customary law and the doctrine of repugnancy, it is usually better to start such examination from the premise of 'internal conflict of laws'. The concept of conflict of laws is usually associated with international law. It is, therefore, necessary to understand the meaning and import of conflict of laws in municipal law. According to Black's Law Dictionary (6th Edition, pp. 299 300), conflict of laws is that:

branch of jurisprudence, arising from the diversity of the laws of different nations, states, or jurisdictions in their application to rights and remedies, which reconciles the inconsistency, or decides which law or system is to govern in the particular case, or settles the degree of force to 
be accorded to the law of another jurisdiction (the acts or rights in question having arisen under it) either where it varies from the domestic law, or where the domestic law is silent or not exclusively applicable in the case in point.

For our purpose, an internal conflict of law arise where a 'foreign law' is at variance with a 'native law' as to which court an action or suit should be brought and by what law that cause or suit is to be decided when the court before which the action is brought assumes jurisdiction (Emiola, 1997). On the assumption of colonial power over the Northern and Southern Protectorates of what is today, known as Nigeria, the British naturally introduced their law to be applied as the territorial law of the new colony. The erection of this foreign legal structure by the colonial power led to the imposition of the English system of law on the local customary law made up of native law and Islamic law (Eshugbaye Eleko v. Government of Nigeria (1931). The English law that were applicable in Nigeria - sometimes referred to as the 'general law' - consist of the common law of England, doctrines of equity, some statutes and orders in council which were applicable in England on the date of reception, and the received law as modified by local legislatures after the attainment of independence on October 1, 1960. This English general law operated side by side with the rules of our customary law and this led to a conflict - which arose from the application of the rules of equity.

The repugnancy doctrine in Nigeria emerged from the decision in the case of Eshugbaye Eleko v. Government of Nigeria. (1931) In that case, Lord Atkin said:

The court cannot itself transform a barbarous custom into a milder one. If it stands in its barbarous character it must be rejected as repugnant to natural justice, equity and good conscience. 
Against this background, the position of the law is that every High Court in Nigeria is empowered to observe and enforce the observance of every customary law of the people in the area of its jurisdiction provided:

(i) That the customary law is not repugnant to natural justice, equity and good conscience, and

(ii) That such customary law must not be incompatible either directly or by implication with any law for the time being in force.

The issue has been whether the locus classicus in Eshugbaye Eleko's case or the repugnancy clause in the High Court law has an 'English colouring' as a result of colonization? Were the British not playing out the role of a bully in subjecting our customary law to their standard of morality?

In Nigeria, customary law may be divided into two classes: (i) ethnic or non-Moslem customary law and (ii) Moslem law. Moslem law is religious law based on the Moslem faith and applicable to members of the faith or those under the influence of Islamic Civilization. It is principally in written form and is comparatively rigid. Ethnic customary law, on the other hand, is unwritten and varies from one ethnic group to another. The diversity of customs is major obstacle to uniformity of customary law systems in Nigeria - especially in the Southern states. This multiplicity is complicated by superstitions, which make proof and judicial notice very difficult. It was against this background that the British subjected our customary law to test to remove superstitious and harsh elements - and to conform it to the universal standard of morality. This explains why Elias has argued that the doctrine of repugnancy has positive effect on the development of our customary law by the elimination of gross injustice inherent in its application (Elias, T. O. (1956). 
Uwais, J. S. C. in Okonkwo v. Okagbue and Ors (1984) has argued that:

equity in its broad sense, as used in the repugnancy doctrine is equivalent to the meaning of 'natural justice' and embraces almost all, if not all, the concept of good conscience............

The logic here is that a good custom or law must conform to the universal concept of what is 'good, just and fair' and this is consistent with section $36(1)$ of the 1999 Nigerian constitution. There is something wrong if a man reaps where he did not sow. This was the issue in Mariyama v. Sadiku Ejo (1961) and Okonkwo v. Okagbue and Ors (1984). In the former, the customary law of the area was that a child born within 10 months after divorce belonged to the divorced husband. On appeal to the High Court, the decision was reversed on the ground that the law was repugnant and the child should be returned to its natural father. In the latter case the Supreme Court declared the custom of 'women to woman marriage' repugnant. In both cases, issues of morality and good conscience influenced judgments. It was immoral to deprive a natural father of his right to his right to his child. A marriage of 'woman to woman' negates the principles of marriage, though new developments are emerging on the issue of same marriage.

There is no known repugnancy case that has been decided on the basis of conflict with any other law. Rather, all repugnancy cases were decided by reference to the universal standard of morality which in human transactions is founded on what is 'good, just and fair'. They were, in fact, decided mostly on moral law. The operation of the repugnancy doctrine in determining the applicability of a customary law should be seen, therefore, only as an instrument used by the British to bring our customary law - as indeed any other law - within the acceptable objective standard of moral law currently recognized by all nations. Throughout history, colonialists including the Romans 
took their laws and customs with them, subjecting colonized territories laws and customs, to test. The application of repugnancy doctrine in Nigeria is the standard practice and therefore, has no 'English colouring'. It could be said that subjecting our customary law to test to bring them within the acceptable objective standard of moral law is a positive aspect of British colonialism.

\section{References}

Black’s Law Dictionary (6th Edition, pp. 299 - 300)

Derrett (1965) Justice, Equity and Good Conscience (Changing Laws in Developing Countries Anderson J. N. D (ed) London: Kegan Paul, Trench, Trubner and Co.

Elias, T. O. (1956): The Nature of African Customary Law, England: Manchester University press.

Emiola, Akintunde (1997): The Principles of African Customary Law. Nigeria: Emiola Publishers.

Eshugbaye Eleko v. Government of Nigeria (1931) AC 262 at 273. Fenton, Edwin (1969): 32 Problems in World History - Source Readings and Interpretations. Glenview, Illinois: Scott, Foresman \& Co.,

Hart, H. L. A. (1961): Law, Liberty and Moral (OUP Paperback), pp. $17-24$.

High Court Law of Bendel State (1976): Section 13 applicable in Edo/Delta States of Nigeria.

Mariyama v. Sadiku Ejo ((1961) NRNLR 81.

Newbury, C. W., (1960) British Policy Towards West Africa: Selected Documents (1875 - 1914), p. 254. London: Hutchinson \& Co. (Publishers) Ltd.

Owonyin, v. Omotosho (1961) 1 ALL NLR 304 at 309.

Oyewumi v. Ogunesan (1990) NWLR 182 at 207.

Seth, Ronald (1960): Children Against Witches. New York: Taplinger, Wiggins, James A., Beverly B. Wiggins and James Vander Zanden (1994): Social Psychology New York: McGraw - Hill. 